\title{
Ruthenium-Catalyzed Oxidative Amidation of Alkynes to Amides
}

\author{
Andrea Álvarez-Pérez, ${ }^{\dagger}$ Miguel A. Esteruelas, ${ }^{\S, *}$ Susana Izquierdo, ${ }^{\S}$ Jesús A. Varela, ${ }^{\dagger}$ and Carlos Saá ${ }^{\dagger, *}$ \\ ${ }^{+}$Centro Singular de Investigación en Química Biolóxica e Materiais Moleculares (CiQUS), Departamento de Química Orgánica, Uni- \\ versidade de Santiago de Compostela, 15782 Santiago de Compostela, Spain \\ 'Departamento de Química Inorgánica-Instituto de Síntesis Química y Catálisis Homogénea (ISQCH)-Centro de Innovación en \\ Química Avanzada (ORFEO-CINQA), Universidad de Zaragoza-CSIC, 50009 Zaragoza, Spain.
}

Supporting Information Placeholder

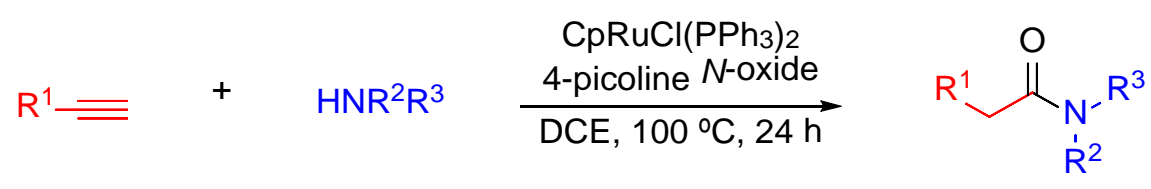

\begin{abstract}
Complex $\mathrm{CpRuCl}\left(\mathrm{PPh}_{3}\right)_{2}$ catalyzes reactions of terminal alkynes with 4-picoline $N$-oxide and primary and secondary amines to afford the corresponding amides. The reactions occur in chlorinated solvent and aqua medium showing applications in peptide chemistry. Stoichiometric studies reveal that the true catalysts of the processes are the vinylidene cations $\left[\mathrm{CpRu}(=\mathrm{C}=\mathrm{CHR})(\mathrm{PPh})_{2}\right]^{+}$which are oxidized to the $\mathrm{Ru}\left(\eta^{2}\right.$-CO)-ketenes by the $\mathrm{N}$-oxide. Finally, nucleophilic additions of primary and secondary amines to the free ketenes yield the corresponding amides.
\end{abstract}

Amide bonds play a crucial role in living organisms and are present in a great number of pharmacologically active compounds. Furthermore, they are widely used as synthetic materials, including nylon, hydrogels, supported catalysts, etc. ${ }^{1}$ The conventional approach to amide formation is the condensation of an amine with a carboxylic acid via an active ester. In the last years, new catalytic methods, which offer alternatives for selective amide bond formation, have emerged to overcome some of the limitations of these standard protocols. ${ }^{2}$ In this context, the use of surrogates of the reaction partners is currently being intensively assayed. ${ }^{1}$ Although terminal alkynes are promising surrogates of acyls in reactions with amines, through catalytic oxidative amidations, their use remains largely underused. ${ }^{3}$

Formation of ketenes ${ }^{4}$ from alkynes is essential for successful amidations. These electrophilic species can be readily formed via rearrangement of oxirene intermediates ${ }^{5}$ or by oxidation of metal vinylidenes, ${ }^{6}$ which are also electrophilic at the carbene center. ${ }^{7}$ Lee recently reported $\mathrm{Rh}$-catalyzed oxidations of terminal alkynes to ketenes, with internal and external oxidants, along with subsequent $[2+2]$ cycloaddition reactions, ${ }^{8}$ or intermolecular trapping with heteronucleophiles, to give lactams, or linear amides. Ruthenium promoted oxidative transformations of terminal alkynes into ketenes, with substrates bearing internal oxidants, ${ }^{9}$ have been also performed, to finally afford efficient intramolecular electrocyclic reactions and intermolecular $[2+2]$ cycloadditions. Following with our interest on the chemistry of M-vinylidenes, ${ }^{10}$ we herein report a new and efficient $\mathrm{Ru}$-catalyzed oxidative amidation of alkynes to primary and secondary amides, using 4-picoline $N$-oxide as external oxidant (Scheme 1). Mechanistic studies indicate that the catalysis involves the oxidation of metal-vinylidene intermediates to free ketenes, which are trapped by the nucleophile. Scheme 1 . Ruthenium catalyzed oxidative amidations of terminal alkynes, using an $\mathrm{N}$-oxide as external oxidant.

$\mathrm{R}=\mathrm{H} \quad+\underset{\mathrm{R}^{2}}{\mathrm{R}^{1}} \stackrel{\substack{\text { [Ru] } \\ \text { external }}}{\mathrm{R}} \underbrace{\mathrm{R}^{1}}_{\substack{\mathrm{N}^{-} \\ \mathrm{R}^{2}}}$

We initially tested the oxidative amidation of phenylacetylenes 1a and $\mathbf{1 b}$ with secondary amines $\mathbf{2} \mathbf{a}$ and $\mathbf{2} \mathbf{b}$ using Rh catalysts (Lee's conditions, Table 1 ). To our initial surprise, while $\mathbf{l a}$ and $\mathbf{l b}$ reacted smoothly with aniline $\mathbf{2 a}$ to give the secondary amides $\mathbf{3 a a}$ and $\mathbf{3 b a}$ in fairly good yields (entry $\mathbf{1}$ ), $\mathbf{1} \mathbf{a}$ and $\mathbf{1} \mathbf{b}$ were recovered when reacted with $\mathbf{N}$-Me-phenethylamine $\mathbf{2 b}$ either in $\mathrm{CH}_{3} \mathrm{CN}$ or DCE or in the presence of catalyst $\mathrm{RhCl}\left(\mathrm{PPh}_{3}\right)_{3}$ (entry 2). ${ }^{8,2 a}$ It was mandatory to use the ammonium salt of $\mathbf{2} \mathbf{b}$ in order to get the corresponding amides $3 \mathrm{ab}$ and $\mathbf{3 b} \mathrm{b}$ in fairly good yields (entry 3 ). ${ }^{3 \mathrm{~b}}$ After this singular behavior of secondary amines under Rh catalysts (aniline 2a vs alkylamine $\mathbf{2 b}$ ), we decided to compare these results against ruthenium catalysts. To our delight, we found that the use of electronrich CpRu catalysts ${ }^{11}$ in non-coordinating $\mathrm{DCE}^{9 e, 12}$ as solvent ${ }^{13}$ gives good to excellent yields of amides $3 \mathbf{a a}, 3 \mathbf{a b}, \mathbf{3} \mathbf{b a}$ and $\mathbf{3 b}$ in two sets of conditions using always the free amines (entries 1-2). Both $N$-oxide (entry 4) or Ru catalyst (entry 5) are required for the reaction to take place (see SI for other conditions tried). 
Table 1. Comparative results of $\mathrm{Rh}$ - and $\mathrm{Ru}$-catalyzed oxidative amidations of arylacetylenes $1 \mathrm{a}, \mathrm{b}$ with secondary amines $2 \mathrm{a}, \mathrm{b}$.

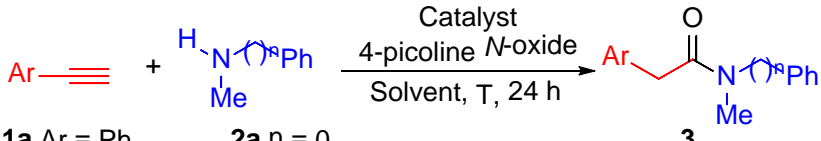

$$
\begin{aligned}
& \text { 1b } \mathrm{Ar}=4-\mathrm{MeOPh} \mathbf{2 b} \mathrm{n}=2
\end{aligned}
$$

\begin{tabular}{|c|c|c|c|c|c|c|}
\hline entry & alkyne & amine & amide & {$[\mathrm{Rh}]^{\mathrm{a}}$ cat } & $\begin{array}{c}\text { Method } A \\
\text { (amine } 2 \text { equiv) }\end{array}$ & $\begin{array}{l}\text { cat }^{\mathrm{b}} \\
\text { Method } B \\
\text { (amine } 1 \text { equiv } / \mathrm{KPF}_{6} 1 \text { equiv) }\end{array}$ \\
\hline 1 & 1a & $2 a$ & $3 a a$ & $79 \%$ & $99 \%$ & $95 \%$ \\
\hline 2 & $1 b$ & $2 a$ & $3 \mathrm{ba}$ & $85 \%$ & $92 \%$ & $90 \%$ \\
\hline 3 & $1 a$ & $2 b$ & $3 \mathrm{ab}$ & $-^{\mathrm{c}, \mathrm{d}}$ & $96 \%$ & $91 \%$ \\
\hline 4 & $1 b$ & $2 b$ & $3 b b$ & $\operatorname{traces}^{\mathrm{a}, \mathrm{d}}$ & $88 \%$ & $89 \%$ \\
\hline 5 & $1 \mathrm{a}$ & $2 \mathbf{b} \cdot \mathrm{HCl}$ & $3 a b$ & $92 \%^{\mathrm{e}}$ & & $96 \%{ }^{\mathrm{f}}$ \\
\hline
\end{tabular}

${ }^{a}$ Reaction conditions $\mathrm{Rh}$ : alkyne 1 ( $\left.0.4 \mathrm{mmol}\right)$, amine 2 (1.2 equiv), $[\mathrm{Rh}(\mathrm{cod}) \mathrm{Cl}]_{2}(3 \mathrm{~mol} \%), \mathrm{P}\left(4-\mathrm{FC}_{6} \mathrm{H}_{4}\right)_{3}(12$ mol \%), 4-picoline $\mathrm{N}$-oxide (1.2 equiv), $\mathrm{CH}_{3} \mathrm{CN}(0.8 \mathrm{~mL}), 60^{\circ} \mathrm{C}{ }^{\mathrm{b}} \mathrm{Ru}$ conditions: alkyne 1 (0.4 mmol), $\mathrm{CpRuCl}\left(\mathrm{PPh}_{3}\right)_{2}(5 \mathrm{~mol} \%), 4$-picoline $\mathrm{N}$-oxide (2 equiv), $\mathrm{DCE}(3 \mathrm{~mL}), 100$ ${ }^{\circ} \mathrm{C}$, amine 2 (2equiv) (Method $A$ ) or amine 2 (1 equiv) $+\mathrm{KPF}_{6}(1 \text { equiv) (method } B)^{\mathrm{c}}$ Starting material recovered either with $\mathrm{CH}_{3} \mathrm{CN}$ or $\mathrm{DCE}$ as solvents. ${ }^{\mathrm{d}} \mathrm{CpRhCl}\left(\mathrm{PPh}_{3}\right)_{3}(6 \mathrm{~mol} \%)$ was used as catalyst. ${ }^{\mathrm{e}} \mathrm{K}_{2} \mathrm{CO}_{3}\left(0.3\right.$ equiv) and $\mathrm{KPF}_{6}$ (1 equiv) were added. ${ }^{\mathrm{f}} \mathrm{K}_{2} \mathrm{CO}_{3}(0.3$ equiv) was added.

The substrate scope varying the nature of the alkyne was then examined under optimized conditions A (Scheme 2). Either electronpoor or electron-rich heteroaryl alkynes also participate as active substrates giving rather good yields of tertiary amides $3 \mathrm{cb}$ and $\mathbf{3 d b}$. In addition, aliphatic and functionalized aliphatic alkynes $(\mathrm{Cl}, \mathrm{OBn})$ as well as enynes were also tolerated to give tertiary amides $3 \mathrm{eb}, 3 \mathrm{fb}$, $3 \mathrm{gb}$ and $\mathbf{3 h b}$, respectively, in fairly good yields. Secondly, other secondary amines were also tested. Thus, five- and six-membered cyclic amines reacted smoothly to give good to excellent yields of cyclic tertiary amides $\mathbf{3 a c}, \mathbf{3 a d}, \mathbf{3 a e}$, and $\mathbf{3 a f}$, respectively. In addition, the linear $\mathrm{N}, \mathrm{O}$-dimethylhydroxylamine and dibenzylamine gave the interesting Weinreb amide ${ }^{14} \mathbf{3 a g}$ and dibenzyl protected amide $3 \mathrm{ah}$ in rather good yields.

Scheme 2. Ru-catalyzed oxidative amidations of alkynes $1 \mathrm{c}-\mathrm{h}$ with secondary amines $2 \mathrm{c}-\mathrm{h}$

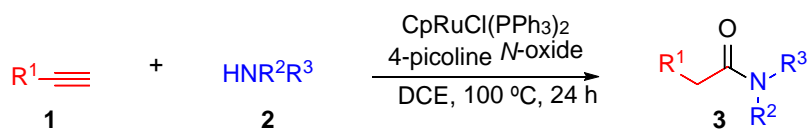

$\mathbf{b}^{\mathrm{a}} \mathrm{R}^{2}=\mathrm{Me}, \mathrm{R}^{3}=\left(\mathrm{CH}_{2}\right)_{2} \mathrm{Ph}$

$\mathrm{F}$<smiles>CN(CCc1ccccc1)C(=O)Cc1ccccc1</smiles><smiles>CN(CCc1ccccc1)C(=O)Cc1ccsc1</smiles>

3 cb $63 \%$

3db $70 \%$

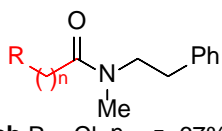

3eb $\mathrm{R}=\mathrm{Cl}, \mathrm{n}=5 ; 67 \%$

3fb $\mathrm{R}=\mathrm{Ph}, \mathrm{n}=3 \cdot 66 \%$

3gb $\mathrm{R}=\mathrm{OBn}, \mathrm{n}=2 ; 73 \%$

$1 \mathrm{a} \mathrm{R}^{1}=\mathrm{Ph}$
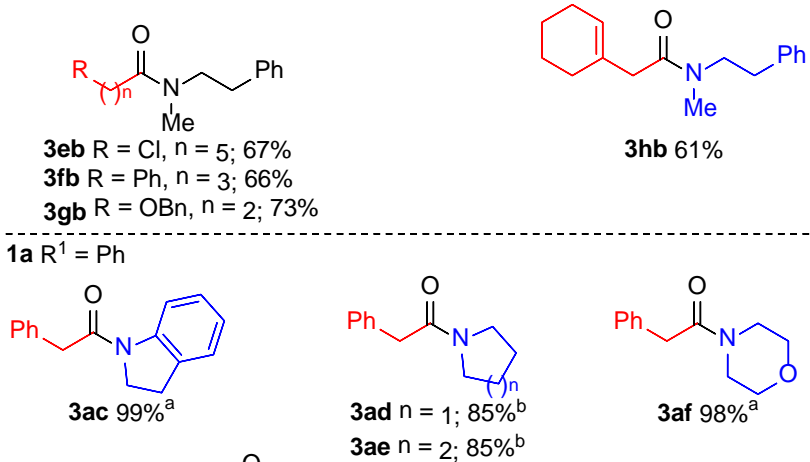

3hb $61 \%$

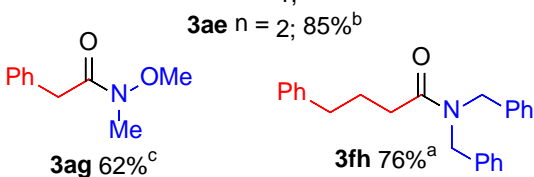

${ }^{a}$ Reaction conditions $\mathrm{A}_{\mathrm{Ru}}{ }^{\mathrm{b}}$ Reaction conditions $\mathrm{B}_{\mathrm{Ru}}{ }^{\mathrm{c}}$ Reaction conditions $\mathrm{B}_{\mathrm{Ru}}$ with $2 \mathrm{~g} \cdot \mathrm{HCl}$ ( 1 equiv) $+\mathrm{K}_{2} \mathrm{CO}_{3}$ (0.3 equiv).

We also evaluated whether this oxidative amidation is suitable for the preparation of the interesting secondary amides (peptide bonds). As we already did with the secondary amines, we tested and compared the oxidative amidations of phenylacetylene 1a with three different primary amines $2 \mathrm{i}-\mathrm{k}$ under $\mathrm{Rh}$ and $\mathrm{Ru}$ catalytic conditions (Table 2). While the employment of Rh catalyst (Lee's conditions $)^{5,15,2 a}$ probed relatively efficient for the preparation of anilide 4ai from aniline $\mathbf{2} \mathbf{i}$ (entry 1, 72\%), it gave lower to negligible yields in the case of phenethyl and benzyl amides 4aj and 4ak from the free 
amines $2 \mathbf{j}$ and $\mathbf{2 k}$ (entries 2 and 3 ). Once again, it was mandatory to use the ammonium salts of $\mathbf{2 j}, \mathbf{k}$ in order to get the corresponding amides 4 aj and 4 ak in excellent yields (entries 2 and 3 ). By contrast, amides 4ai-4ak were always obtained in excellent yields from the free amines $2 \mathrm{i}-\mathrm{k}$ using Ru catalysts (entries 1-3). Scaling was also possible since amide 4 ak could be obtained in $94 \%$ isolated yield using $1 \mathrm{mmol}$ of alkyne $1 \mathrm{a}$.

Table 2. Comparative results of $\mathrm{Rh}$ - and $\mathrm{Ru}$-catalyzed oxidative amidations of phenylacetylene $1 \mathrm{a}$ with primary amines $2 \mathrm{i}, \mathrm{j}, \mathrm{k}$.

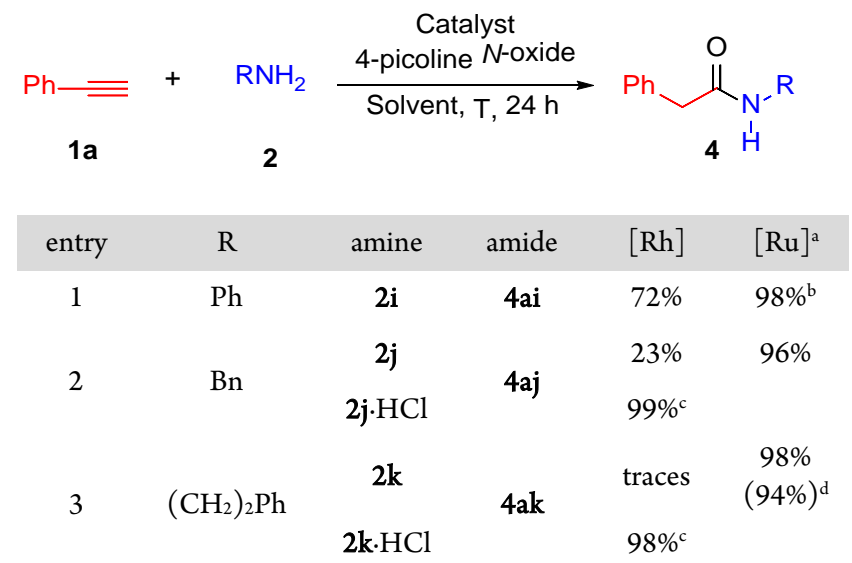

a Method B. ${ }^{\text {b }}$ A mixture of $\mathrm{H}_{2} \mathrm{O} / \mathrm{DCE}$ 95:5 was used as solvent. ${ }^{\mathrm{c}}$ $\mathrm{K}_{2} \mathrm{CO}_{3}$ ( 0.3 equiv) and $\mathrm{KPF}_{6}$ ( 1 equiv) were added. ${ }^{\mathrm{d}}$ Isolated yield using $1 \mathrm{mmol}$ of $1 \mathrm{a}$.

The substrate scope varying the nature of the alkyne was first examined (Scheme 3). The (trimethylsilyl)acetylene $1 \mathbf{i}$ was found to be a good substrate for this amidation reaction to deliver the desilylated $N$-acetyl amide 4ik in excellent yield. Gratifyingly, functionalized aliphatic alkynes bearing $\mathrm{CN}, \mathrm{NHAc}, \mathrm{OBn}$ and $\mathrm{Cl}$ groups as well as enynes and aromatic diynes were all well tolerated to afford moderate to excellent yields of the corresponding amides $4 \mathrm{jk}-4 \mathrm{pk}$ '. Then, variation of the amine partner was analyzed. Either simple methylamine $\mathbf{2 l}$ or functionalized allyl- and propargylamines $\mathbf{2 m}$ and $\mathbf{2 n}$ gave moderate to good yields of the corresponding amides 4al-4an. Pleasingly, 2-(aminomethyl)aniline 2o, a difunctional aniline and benzyl amine, could be conveniently diacylated to give the diamide 4ao in fairly good yield. Natural alkaloids bearing primary amines like (-)leelamine $2 \mathrm{p}$ and tryptamine $2 \mathbf{q}$ were also acylated to the corresponding amides $4 \mathrm{ap}$ and $4 \mathrm{aq}$ with very good yields. Interestingly, oxidative amidations with the more challenging chiral secondary (R)-1-phenylethylamine $\mathbf{2 r}$ and tertiary tert-butylamine $2 \mathrm{~s}$ smoothly occurred to give the chiral secondary amide 4ar and $\mathrm{N}$ (tert-butyl)phenylacetamide 4as with excellent yields.

Scheme 3. Ru-catalyzed oxidative amidations of alkynes $1 \mathrm{i}-1 \mathrm{p}$ with primary amines $21-2 s^{2}$

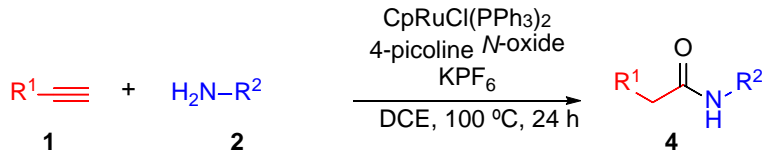

$2 \mathrm{k} \mathrm{R}^{2}=(\mathrm{CH} /)_{2} \mathrm{Ph}$

4ik $97 \%^{b}$

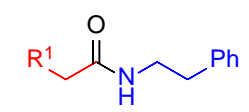

4jk $\mathrm{R}^{1}=\left(\mathrm{CH}_{2}\right){ }_{4} \mathrm{CN} ; 97 \%$

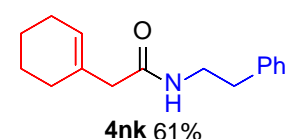

4kk R $\mathrm{R}^{1}=\left(\mathrm{CH}_{2}\right)_{2} \mathrm{NHAc} ; 98 \%$

$4 \mathrm{lk} \mathrm{R}^{1}=\left(\mathrm{CH}_{2}\right)_{2} \mathrm{OBn} ; 80 \%$

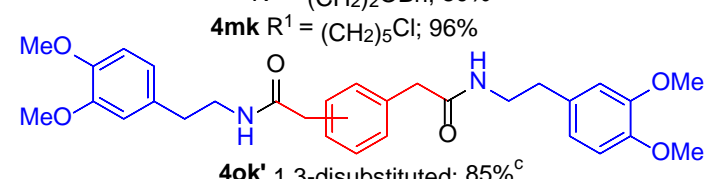

4ok' 1,3-disubstituted; $85 \%{ }^{\mathrm{c}}$

4pk' 1,4-disubstituted; $83 \%{ }^{\mathrm{c}}$

$$
1 \mathrm{a} \mathrm{R}^{1}=\mathrm{Ph}
$$

4al $84 \%{ }^{d}$

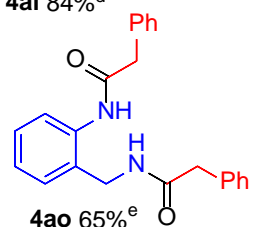

(1)

4aq $78 \%$

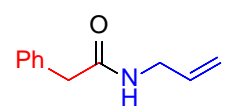

4am 53\%

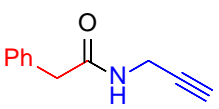

4an $75 \%$
${ }^{a}$ Reaction conditions $B_{\mathrm{Ru} .}{ }^{\mathrm{b}}$ (Trimethylsilyl)acetylene $1 \mathrm{i}$ was used. ${ }^{\mathrm{c}} 1 \mathrm{o}$ 1,3-diethynylbenzene, 1p 1,4-diethynylbenzene. ${ }^{\mathrm{d}}$ Reaction conditions $\mathrm{B}_{\mathrm{Ru}}$ with $21 \cdot \mathrm{HCl}+\mathrm{K}_{2} \mathrm{CO}_{3}\left(0.3\right.$ equiv) ${ }^{\mathrm{e}} \mathbf{1 a}$ (2 equiv) were used.

The oxidative amidation not only occurred in boiling chlorinated solvents but also in aqueous media at $37^{\circ} \mathrm{C}$ which foresees interesting applications in peptide chemistry (Scheme 4). Thus, excellent yields of the secondary amide 4ai (98\%) were obtained when the reaction was run either in pure DCE or in a mixture DCE/ $\mathrm{H}_{2} \mathrm{O}$ 5:95 (Table 2). Oxidative amidations of phenylacetylene 1a with methylester derivatives of $(L)$-aminoacids bearing primary amines such as phenylglycine $\mathbf{8 a}$, serine $\mathbf{8 b}$ and $\mathrm{MeS}$-cysteine $\mathbf{8 c}$ and secondary amines such as proline $\mathbf{8 d}$ smoothly occurred to give the corresponding $N$-acyl derivatives 9aa-9ad in excellent yields. Interestingly, the oxidative amidation end up completely chemoselective since reaction only by the more nucleophilic amino group of serine $\mathbf{8 b}$ was observed. On the other hand, oxidative amidations of $N$ nosyl- $N$-propargyl $\gamma$-aminoester $\mathbf{1} \mathbf{q}^{16}$ occurred uneventfully to give the amidoester derivatives $9 \mathrm{qd}$ and $9 \mathrm{qe}$ in quite good yields. ${ }^{17}$

Scheme 4 . Ru-catalyzed oxidative amidations of alkynes 1 with aminoesters 8 in aqueous media at $37^{\circ} \mathrm{C}$. $^{a}$ 


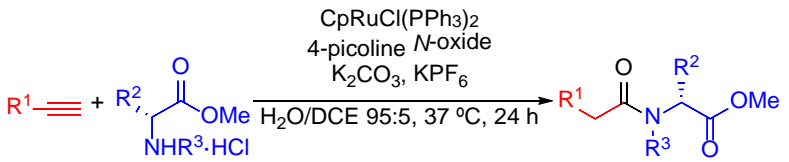

$$
\begin{aligned}
& 1 \\
& 8 \\
& 9
\end{aligned}
$$

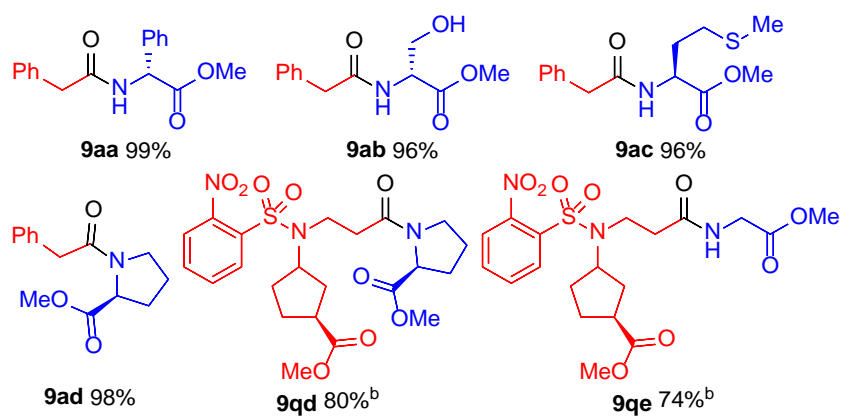

a Reaction conditions: alkyne 1 ( $0.4 \mathrm{mmol})$, aminoester $\mathrm{HCl} 8$ (1 equiv), $\mathrm{CpRuCl}\left(\mathrm{PPh}_{3}\right)_{2}$ (5 mol\%), 4-picoline $N$-oxide (1.1 equiv), $\mathrm{KPF}_{6}$ (1 equiv), $\mathrm{K}_{2} \mathrm{CO}_{3}$ (0.3 equiv), $\mathrm{H}_{2} \mathrm{O} / \mathrm{DCE}(3 \mathrm{~mL}), 37^{\circ} \mathrm{C}, 24 \mathrm{~h} .{ }^{\mathrm{b}}$ 4-picoline $\mathrm{N}$-oxide ( 2 equiv), $100^{\circ} \mathrm{C}, 24 \mathrm{~h}$.

To gather information about the mechanism of the amination, we reproduced the elemental steps of the catalysis through stoichiometric reactions performed at room temperature. In DCE, the ruthenium complex $\mathrm{CpRuCl}\left(\mathrm{PPh}_{3}\right)_{2}$ reacts with phenylacetylene (1a) in the presence of $\mathrm{KPF}_{6}$ to give the previously reported vinylidene salt $\left[\mathrm{CpRu}(=\mathrm{C}=\mathrm{CHPh})\left(\mathrm{PPh}_{3}\right)_{2}\right] \mathrm{PF}_{6}{ }^{18}(5)$, as a result of the extraction of the chloride anion and the alkyne-vinylidene tautomerization of the hydrocarbon. Phosphine dissociation is not observed. The addition of the stoichiometric amount of 4-picoline $\mathrm{N}$-oxide to a NMR tube containing a dichloromethane- $d_{2}$ solution of $\mathbf{5}$ smoothly affords a mixture of $5(10 \%)$, the picoline derivative $[\mathrm{CpRu}(4-\mathrm{Me}-$ py) $\left.\left(\mathrm{PPh}_{3}\right)_{2}\right] \mathrm{PF}_{6}{ }^{19}(6 ; 59 \%)$ and a $\mathrm{Ru}-\mathrm{C}(=\mathrm{O}) \mathrm{CH}_{2} \mathrm{Ph}$ acyl species (31\%). Noticeable spectroscopic features of the latter are a singlet at 3.34 ppm due to the $\mathrm{CH}_{2}$ group in the ${ }^{1} \mathrm{H}$ NMR spectrum, two singlets at 194.5 and $48.1 \mathrm{ppm}$ corresponding to the $\mathrm{CO}$ and $\mathrm{CH}_{2}$ acylcarbon atoms in the ${ }^{13} \mathrm{C}\left\{{ }^{1} \mathrm{H}\right\}$ NMR spectrum, and a singlet at 39.0 ppm in the ${ }^{31} \mathrm{P}\left\{{ }^{1} \mathrm{H}\right\}$ NMR spectrum. Its formation is a strong indirect evidence of the oxidation of the $\mathrm{Ru}=\mathrm{C}$ bond of 5 to give a $\mathrm{Ru}\left(\eta^{2}\right.$ $\mathrm{CO})$-ketene intermediate, ${ }^{20}$ which is trapped by traces of water present in the medium (Scheme 5). The dissociation of the ketene and the subsequent coordination of the generated 4-picoline leads to 6 . In addition, it should be pointed out that traces of phosphine oxide does not observe. The formation of the acyl species does not appear to take place under catalytic conditions; i.e., in the presence of an excess of amine. When 4-picoline $\mathrm{N}$-oxide and benzylamine $(\mathbf{2} \mathbf{j})$ were added to the dichloromethane- $d_{2}$ solution of $5, \mathrm{~N}$-benzyl-2phenylacetamide (4aj) and 6 were formed. Complex 6 reacts with phenylacetylene to regenerate the vinylidene 5 and release 4-picoline. ${ }^{21}$

Scheme 5. Formation of the acyl species.

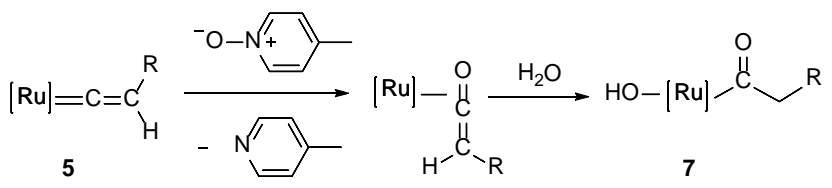

$[\mathrm{Ru}] \equiv\left[\mathrm{CpRu}\left(\mathrm{PPh}_{3}\right)_{2}\right]^{+}$
The previously mentioned stoichiometric results reveal that: i) complex $\mathrm{CpRuCl}\left(\mathrm{PPh}_{3}\right)_{2}$ is the catalytic precursor, whereas the vinylidene derivative $\mathbf{5}$ is the true catalyst of the amidation; ii) the catalysis takes place via $\mathrm{Ru}\left(\eta^{2}-\mathrm{CO}\right)$-ketene intermediates, which are formed by oxygen transfer from 4-picoline $\mathrm{N}$-oxide; iii) 4-picoline, which is generated from the oxidation of the vinylidene, displaces the ketene from the ruthenium coordination sphere; and iv) the formation of the amide is an outer-sphere process involving the capture of the released ketene by the amine. The cycle shown in Scheme 6 summarizes these features.

Scheme 6. Mechanism proposed for the Ru-catalyzed oxidative amidation of terminal alkynes with amines.

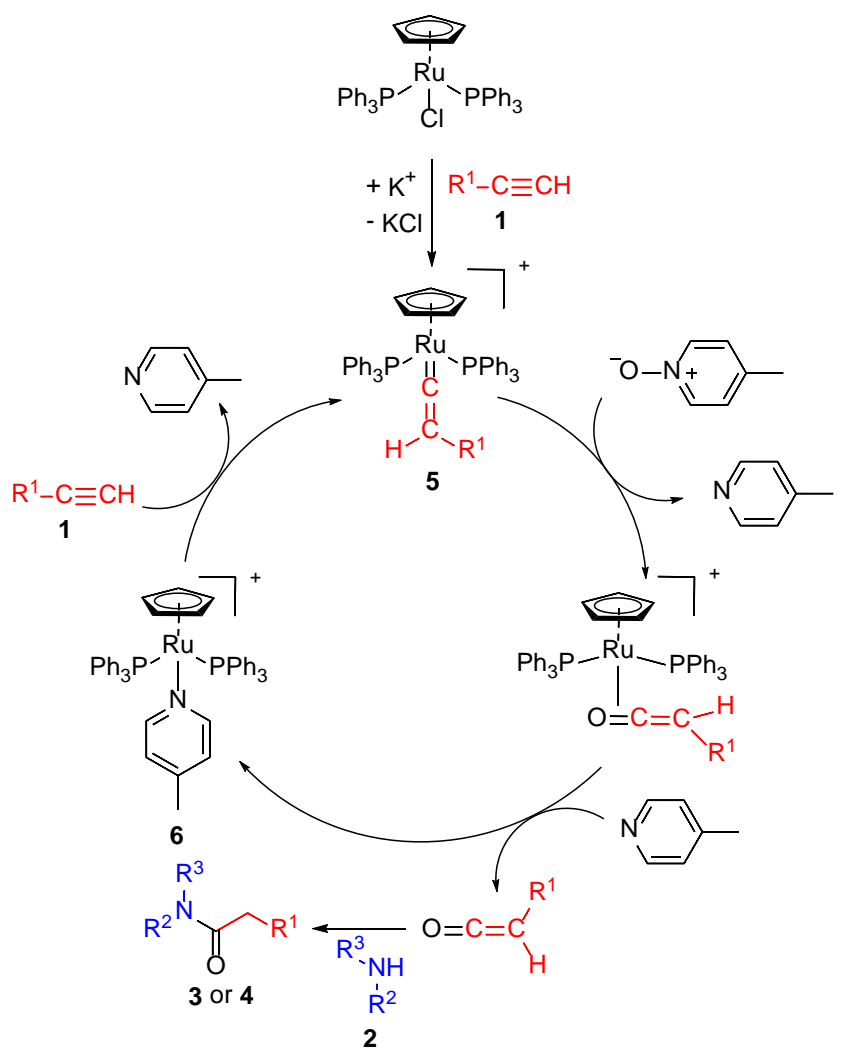

In conclusion, efficient ruthenium-catalyzed oxidative amidations of alkynes to primary and secondary amides have been developed using 4-picoline $N$-oxide as external oxidant. Remarkably, the catalysis not only takes place in chlorinated solvents but also in aqueous media, which opens challenging applications in peptide chemistry. The process occurs by conversion of terminal alkynes to Ru-ketenes via oxidation of the initially formed $\mathrm{Ru}$-vinylidene intermediates. Ketenes are released and trapped by the nucleophilic primary and secondary amines to yield the corresponding amides.

\section{ASSOCIATED CONTENT}

\section{Supporting Information}

The Supporting Information is available free of charge on the ACS Publications website.

Detailed experimental procedures and compound characterization data (PDF)

\section{AUTHOR INFORMATION}

\section{Corresponding Author}


*carlos.saa@usc.es, maester@unizar.es

\section{ACKNOWLEDGMENT}

This work has received financial support from MINECO (projects CTQ2014-59015R, CTQ2017-87939R, CTQ2017-82935-P and ORFEO-CINQA network CTQ2016-81797-REDC), the Xunta de Galicia (project GRC2014/032, ED431C 2018/04, Centro singular de investigación de Galicia accreditation 2016-2019, ED431G/09), DGA (No.E06 17R) and the European Union (European Regional Development Fund - ERDF). A. A.-P. thanks Spanish MICINN for a predoctoral FPI fellowship. We thank Prof. J. Granja (CiQUS) for a generous gift of aminoester derivatives.

\section{REFERENCES}

(1) (a) Pattabiraman, V. R.; Bode, J. W. Nature 2011, 480, 471-479. (b) deFigueiredo, R. M.; Suppo, J.-S.; Campagne, J.-M. Chem. Rev. 2016, 116, 12029-12122.

(2) (a) Ishihara, K.; Lu, Y. Chem. Sci. 2016, 7, 1276-1280. (b) Krause, T.; Baader, S.; Erb, B.; Gooßen, L. J. Nat. Commun. 2016, 7, 11732. (c) Lundberg, H.; Tinnis, F.; Zhang, J.; Algarra, A. G.; Himo, F.; Adolfsson, H. J. Am. Chem. Soc. 2017, 139, 2286-2295. See also refs. 1.

(3) (a) Chan, W.-K.; Ho, C.-M.; Wong, M.-K.; Che, C.-M.J. Am. Chem. Soc. 2006, 128, 14796-14797. (b) Kim, I.; Lee, C. Angew. Chem. Int. Ed. 2013, 52, 10023-10026.

(4) For a recent review, see: Allen, A. D.; Tidwell, T. T. Eur. J. Org. Chem. 2012, 1081-1096.

(5) Erden, I., Oxiranes and Oxirenes: Monocyclic. In Comprehensive Heterocyclic Chemistry II, Katritzky, A. R.; Rees, C. W.; Scriven, E. F. V., Eds.; Elsevier, 1996; Vol. 1A, pp 97-144.

(6) Roh, S. W.; Choi, K.; Lee, C. Chem. Rev. 2019, DOI: 10.1021/acs.chemrev.8b00568.

(7) Metal Vinylidenes and Allenylidenes in Catalysis; From Reactivity to Application in Synthesis, Bruneau, C.; Dixneuf, P., Eds.; Wiley-VCH, 2008.

(8) Kim, I.; Roh, S. W.; Lee, D. G.; Lee, C. Org. Lett. 2014, 16, 2482-2485.

(9) (a) Lin, M.-Y.; Madhushaw, R. J.; Liu, R.-S.J. Org. Chem. 2004, 69, 77007704. (b) Madhushaw, R. J.; Lin, M.-Y.; Sohel, S. M. A.; Liu, R.-S. J. Am. Chem. Soc. 2004, 126, 6895-6899. (c) Lin, M.-Y.; Maddirala, S. J.; Liu, R.-S. Org. Lett. 2005, 7, 1745-1748. (d) Pati, K.; Liu, R.-S. Chem. Commun. 2009, 5233-5235. (e) Wang, Y.; Zheng, Z.; Zhang, L. Angew. Chem. Int. Ed. 2014, 53, 9572-9576.

(10) (a) Varela-Fernández, A.; García-Yebra, C.; Varela, J. A.; Esteruelas, M. A.; Saá, C. Angew. Chem. Int. Ed. 2010, 49, 4278-4281. (b) Batuecas, M.; Escalante, L.; Esteruelas, M. A.; García-Yebra, C.; Oñate, E.; Saá, C. Angew. Chem. Int. Ed. 2011, 50, 9712-9715. (c) Buil, M. L.; Esteruelas, M. A.; Garcés, K.; Oñate, E. J. Am. Chem. Soc. 2011, 133, 2250-2263. (d) Varela-Fernández, A.; Varela, J. A.; Saá, C. Adv. Synth. Catal. 2011, 353, 1933-1937. (e) Álvarez-Pérez, A.; González-Rodríguez, C.; García-Yebra, C.; Varela, J. A.; Oñate, E.; Esteruelas, M. A.; Saá, C. Angew. Chem. Int. Ed. 2015, 54, 13357-13361. (f) Varela, J. A.; González-Rodríguez, C.; Saá, C. Top. Organomet. Chem. 2015, 48, 237-287.

(11) Catalytic combinations of $\left[\mathrm{Ru}(\mathrm{p}-\mathrm{cym}) \mathrm{Cl}_{2}\right]_{2}$ and $\mathrm{PPh}_{3}$ or electron-poor and electron-rich phosphines met with failures. See Supp Info for details.

(12) Sherwood, J. Angew. Chem. Int. Ed. 2018, 57, 14286-14290.

(13) The reaction failed or gave traces of amide formation in the typically used apolar toluene or coordinating $\mathrm{CH}_{3} \mathrm{CN}$. See Supp Info for details.

(14) Nahm, S.; Weinreb, S. M. Tetrahedron Lett. 1981, 22, 3815-3818.

(15) Erden, I., Oxiranes and Oxirenes: Fused-Ring Derivatives. In Comphehensive Heterocyclic chemistry II, Katritzky, A. R.; Rees, C. W.; Scriven, E. F. V., Eds.; Elsevier, 1996; Vol. 1A, pp 145-171.

(16) Fuertes, A.; Ozores, H. L.; Amorín, M.; Granja, J. R. Nanoscale 2017, 9, 748-753.

(17) Amides $3 \mathrm{bj}-\mathrm{k}$, $3 \mathrm{bn}$ and $3 \mathrm{br}$ could be also obtained by reaction of alkyne $1 \mathrm{~b}$ with the corresponding amine $2 \cdot \mathrm{HCl}$ in aqueous media at $37^{\circ} \mathrm{C}$. For amide $\mathbf{3} \mathbf{b} \mathbf{i}$, free amine $\mathbf{2} \mathbf{i}$ was used. Alkyne $\mathbf{1 b}$ was partially recovered unchanged. See Supp Info for details.

(18) Bruce, M. I.; Wallis, R. C. Aust. J. Chem. 1979, 32, 1471-1485.

(19) Moreno, V.; Font-Bardia, M.; Calvet, T.; Lorenzo, J.; Avilés, F. X.; Garcia, M. H.; Morais, T. S.; Valente, A.; Robalo, M. P. J. Inorg. Biochem 2011, 105, 241-249.
(20) For the observation of $\operatorname{Ir}\left(\eta^{2}-\mathrm{CO}\right)$ ketene complexes, see: Grotjahn, D. B.; Lo, H. C. Organometallics 1995, 14, 5463-5465.

(21) An altenative mechanistic proposal based on initial formation of aminocarbene (by trapping of the vinylidene 5 with the amine 2 ) followed by its oxidation with the $N$-oxide occurs very slowly and was therefore ruled out. 